\title{
Climate change impoverishes and homogenizes ants' community structure: a long term study
}

\author{
L. Gallé
}

\author{
Department of Ecology, University of Szeged, Szeged, Közép fasor 52, H-6726, Hungary \\ E-mail: galle@bio.u-szeged.hu
}

Keywords: Ants, long-term population dynamics, Climate, Groundwater table.

\begin{abstract}
Climate change brings along trend-like changes as well as changes in the temporal variations in environmental conditions which interact with the biological dynamics of ecological systems. Therefore, only studies covering several decades may unveil long term trends in ecological systems, such as in animal communities. To demonstrate if recent climatic changes have caused fundamental changes in the structure of a key arthropod community, I studied the long-term dynamics of ant colonies for 37 years on a sandy grassland in central Hungary. To be able to monitor colonies - the natural units of ant communities - with the possible least disturbance, I applied two grids of a total of 80 slate plates as artificial nesting sites. Prior to the presented study, a well-defined spatial ant community structure had been identified in the studied habitat, which consisted of three species groups (dune top, transitional and dune slack groups), occupying different habitat patches. During the study period 2813 nests of 11 ant species were recorded under the slates. Over the 37 years, community pattern markedly changed, dune slack species disappeared from the studied plots, while the frequency of drought-tolerant dune top species increased by a significant trend. No significant trend was observed in the case of the transitional species group. On the species population level, two species, Lasius niger and Formica cunicularia, showed an intensive population decline; while the Plagiolepis taurica population significantly increased and spatially joined the transitional species group in the dune slack in the second half of the project. These changes led to a major decline in species richness and a homogenization of species composition across habitat patches. Multiple correlation analyses revealed that the depletion of groundwater had the strongest relationship with these population trends. The study indicates that climate change can be linked to a fundamental change in the community structure of major ecosystem actors.
\end{abstract}

Nomenclature: Csősz et al. (2011) for ants, Simon (1992) for plants.

\section{Introduction}

As a result of anthropogenic stresses and disturbances, ecosystems frequently undergo transformations leading to the decline of biodiversity. Global climate change is increasingly becoming a key driver of ecosystem changes, but we largely lack truly long term data about these processes, mostly because of the relatively recent recognition of the need for such studies. Ecological monitoring programs and the resulting long-term datasets (Magurran et al. 2010, Thomsen et al. 2012) are essential for discovering the species' response to ongoing environmental change and generating quantifiable evidence of conservation successes in preventing negative impacts of projected changes in climate (Lindenmayer et al. 2012). Monitoring programs could be based on either longterm ecological studies or on assessment of the effects of stress or disturbance (see Elzinga et al. 2001).

Ants are regarded as one of the invertebrate taxa which are especially suitable for ecological monitoring and indication studies (see e.g., Agosti et al. 2000 for a book on ant monitoring). Besides their indication similarity to several invertebrate groups, they have high density, considerable biomass, suitable species number and they are also active 'ecosystem engineers' (Folgarait 1998). Moreover, ants are sensitive indicators of environmental and ecosystem changes (Andersen 2010). Another advantage of this group is that dispersing propagula (winged females and males) can easily be distinguished from already successfully settled population units, i.e., colonies with workers.

As ants are sensitive indicators, one can expect that many long-term studies dealing with ant communities' reactions to climate change have been published. However, as Dunn et al. (2009) pointed out, studies focusing on the relationship between climate change and long-term ant community dynamics are scarce and mostly restricted to the distribution of invasive species (e.g., Levia and Frost 2004, Roura-Pascual et al. 2004, Morrison et al. 2005, Suarez et al. 2010, Bertelsmeier et al. 2016). Therefore, research on the reaction of non-invasive ant species or assemblages to climate change can be regarded as stopgap studies.

Climate change is a well-known, world-wide process, but the intensity of its effects differs from region to region. The particular site selected for this study is in Kiskunság (central Hungary, Carpathian Basin, Pannon Ecoregion), where global warming has especially intensive consequences: the original temperate climate is gradually transforming into semi-arid type and the depletion of the groundwater table is faster than in other regions of the Carpathian Basin and these trends con- 
tinued during the period of present study (Rakonczai 2011, Rakonczai and Ladányi 2012, Rakonczai and Fehér 2015, Ladányi et al. 2015). Therefore, it is a suitable location for studying the ecological effects of climate change.

The general aim of the present study was long-term monitoring of ant community dynamics in a changing climate. The main objectives were: (i) trend monitoring of ants over a 37 year period on the level of single-species populations and their collectives grouped on the basis of coordinated coexistence in different habitat patches and (ii) to seek correlations between population trends and elements of climate change.

\section{Materials and methods}

\section{Study site}

The study was carried out on a sandy grassland near the village Bugacpusztaháza in the Kiskunság National Park, central Carpathian Basin (N 46.696414, E 19.603203, see also Gallé et al. 2014). The original vegetation of the region was forest-steppe, consisting of solitary trees and smaller or larger patches of forest surrounded by grasslands where dead twigs, barks and logs fallen from trees provided nesting shelters for both forest and grassland ants. The particular study site consisted of small dunes, not higher than $3.5 \mathrm{~m}$, with dry sandy soil and sparse vegetation, and between-dune slacks with more humid soil and denser vegetation. From the ca. 5000 ha pasture, a 2.4 ha plot was isolated by fencing in 1976 to exclude grazing and other disturbing factors. The isolation resulted in a secondary succession process starting from grazed condition, characterized by Potentilla arenaria and Festuca pseudovina, approaching a natural state of the vegetation. For the purpose of the present study, I selected a dune ridge and a slack, where the vegetation succession was in the terminal grassland stage without trees and natural shelters. The vegetation on the dune ridge is open grassland predominated by Festuca vaginata, Stipa borysthenica, Euphorbia segueriana, Dianthus serotinus and in dryer years Stipa capillata and Secale sylvestre. The slack vegetation is characterized by Molinia hungarica, dwarf Salix repens ssp. rosmarinifolia bushes with Festuca pseudovina and Potentilla arenaria at the edges of the slack.

Altogether 30 ant species have been published from the study plot (Gallé and Szőnyi 1988, Kanizsai et al. 2009). On the basis of their ecological characters and habitat preferences, these species could be classified into three groups: (1) thermophilous and drought tolerant species of the dune tops (predominant species are Lasius psammophilus and Plagiolepis taurica, the third characteristic species is Formica cunicularia with lower density, see Gallé 1980); (2) slightly more hygrophilous species occurring in dune slacks (Lasius niger, Myrmica schencki, Formica saguinea, Formica rufibarbis) and (3) species of habitats transitional either in secondary succession or that are in belts between dunes and slacks (Tetramorium cf. caespitum, Tapinoma subboreale, Lasius bombycina).

\section{Nest density estimation}

Two grids of slate plates as artificial nesting sites were used to estimate the density of ant nest. In 1981, 40 slate plates, sized $40 \mathrm{~cm} \times 40 \mathrm{~cm} \times 0.3 \mathrm{~cm}$, were placed on the dune top and another 40 plates in the dune slack (Fig. 1), and were left there until 2017. During the whole period only broken ones were replaced. All slates were of the same type ("TÜZÉP 40x40 síkpala"). The slates were arranged in a grid

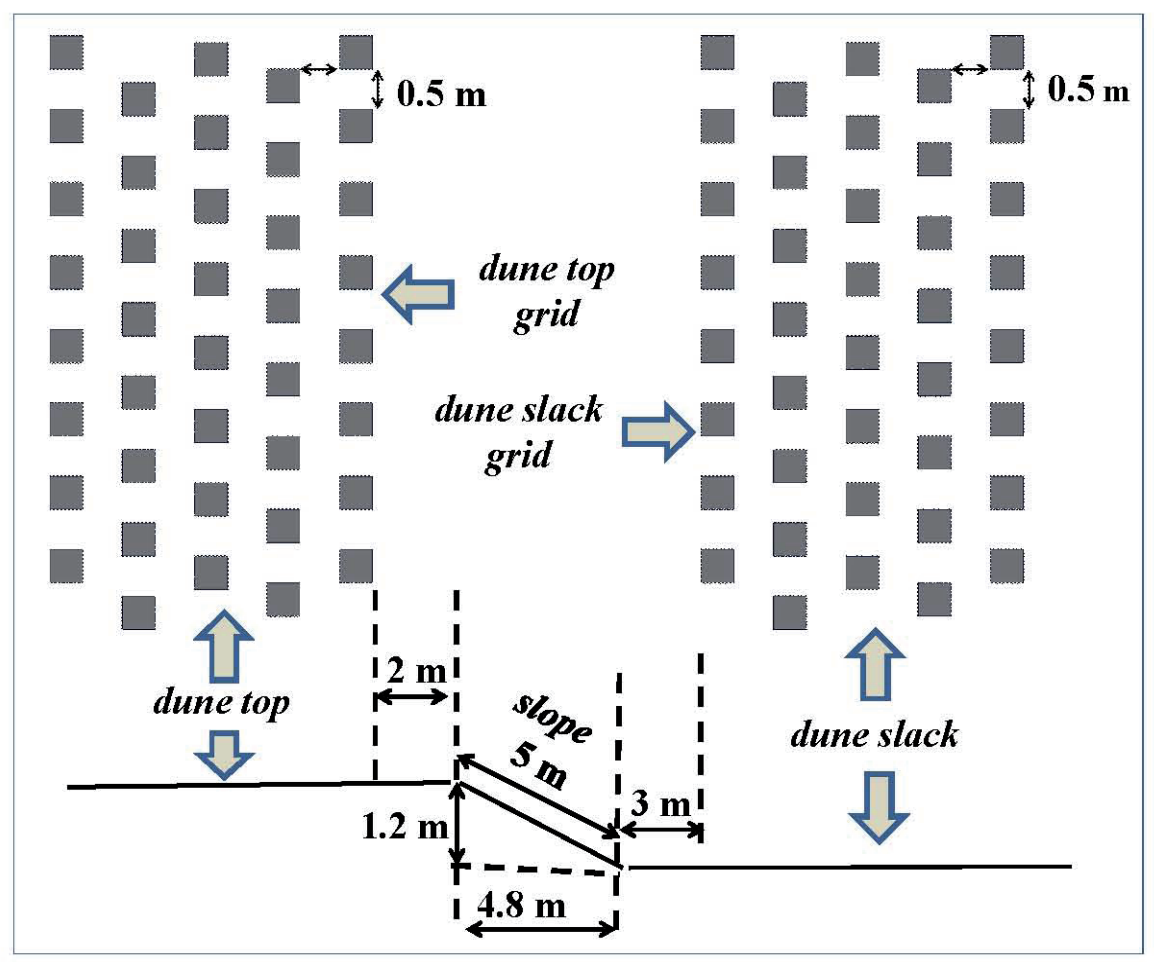

Figure 1. Positions of slate plate grids. 
and the distance between adjacent plates was $50 \mathrm{~cm}$; therefore, an ant colony could easily reach and occupy any of them.

I measured the temperature under the slates, at $5 \mathrm{~cm}$ depth in the soil at $15 \mathrm{~cm}$ distance from the edge of the slates, at 1 $\mathrm{m}$ heights in the air and $\sim 3 \mathrm{~cm}$ above the soil surface in herb layer 27 times with at least five replicates using Testo 925 digital thermometers.

Ants colonized the soil under the slates in spring and, to a lesser extent, also in autumn, because the temperature there exceeded that of the ambient soil. The temperature differences (mean: $9.22^{\circ} \mathrm{C}, \mathrm{n}_{\text {observations }}=135, \mathrm{SE}=0.39$ ) were significant in all observations (Student's t-test, $\mathrm{p}<0.001$ in most cases). The raised temperature under the slates did not influence that of the neighbouring soil. As the temperature under the plates was too high during summer, ants left and recolonized them again in autumn and/or in the next spring after overwintering deep in the soil. The ant colonies presumably survived for several years and new ones were also established during the study period.

A total of 51 observations were carried out during the 37 years, during which 4080 slates were checked. The colonies were counted and identified by lifting the slates, which caused only a slight disturbance without destroying the nests. I regarded big groups of individuals with nest galleries, entrances and/or brood as colonies. As the occupation frequency was higher in spring than in autumn, I considered only spring data in further analysis ( $>85 \%$ of all observations). Due to technical reasons, there was no appreciable census in seven years, while in certain years more than one observation was performed at different temperatures to detect the highest occupation and its dependence on temperature. The highest occupation rate was between 9 and $15^{\circ} \mathrm{C}$ air temperature, and between 8 and $13^{\circ} \mathrm{C}$ soil temperature, respectively, corresponding to the temperature range of $18-26^{\circ} \mathrm{C}$ under the slates. The results of observations with the highest occupation rates were considered for further analysis.

During the observations I identified the ant species occupying the plates and counted the number of their nests under each plate. The frequency of species groups is given as a sum of nests of the ant species belonging to the group in question. Changes of species populations were analysed for the most frequent species

\section{Environmental predictors}

Out of the environmental variables, I analysed the potential effect of the annual mean temperature (te), the annual rainfall (rf) and the level of ground water table (wt) on ant population changes. As the ant colonies survived permanently, it was reasonable to choose annual means. To model population changes I respectively took into account these three environmental predictors one, two and three years before the year of a given spring observation. Environmental conditions of the given year were only considered by the single variable ground water level, since values of the other variables were largely influenced by weather conditions occurring after the spring observations. Environmental data were obtained from
Rakonczai 2011, Rakonczai and Ladányi 2012, Ladányi et al. 2015 (for wt) and the Hungarian Meteorological Agency (www.met.hu, for te and rf).

\section{Statistical treatments}

In most cases, the traditional and usual statistics were sufficient for data evaluation. I employed the non-parametric Mann-Kendall test (Gilbert 1987, Elzinga et al. 2001) to analyse population trends.

Depending on the distribution of variables, either Pearsons' product-moment correlation or Sperman's rank correlation was applied as a measure of intensity of pairwise association between trends of ant populations and potential environmental variables. I tested the quantitative change of the studied ant populations with respect to the presumed environmental variables with linear models (LM) and multiple correlation analysis. A stepwise model selection was carried out with Akaike criterion and only the selected versions occur in Table 2. For these statistics, the distribution of residuals was investigated with QQ plot. Most of computations were done with $\mathrm{R}$ version 3.1.2. (R Core Team 2014).

\section{Results}

\section{Density of ant nests}

I recorded a total of 2813 nests of 11 ant species under the plates in 4080 individual slate checks between 1981 and 2017.

The total number of nests observed under slates on one observation occasion varied between 57 and 114 from the second year of observations, with an average of 85.28 and a coefficient of variation of 0.18 . Relating these data to the whole area where slates were used, 1.56 nest $/ \mathrm{m}^{2}$ mean ant nest density was obtained. The first year's figure was only 42 nests, presumably because of the disturbance caused by laying the slates (Fig. 2). The number of all ant nests slightly increased (Mann-Kendall statistics ZMK $=3.58, \mathrm{p}=0.0003$ ) during the observation period with a slope of 0.83 .

\section{Temporal trends of ant species groups and populations}

The percentage ratios of the original dune top, dune slack, and transitional species groups for the whole study period were $75: 4: 21$, respectively, considering only the first four years they were $65: 16: 19$, while in the last 4 years $92: 0: 8$ (Fig. 3).

Significant increasing tendency was observed in the case of the dune top species group (Mann-Kendall ZMK $=4.41$, $\mathrm{p}<0.0001$ ), while the trend of slack group was negative (Mann-Kendall ZMK $=17.44, p<0.0001$ ) and species of the latter group disappeared from the sampled slack by the end of the study (Fig. 3). The trend of transitional group, occurring mostly in the slack during the study period, was not significant $(\mathrm{ZMK}=0.104, \mathrm{~ns})$, but also had a decreasing tendency. 
Table 1. Mann-Kendall trend analysis of the most common populations

\begin{tabular}{lcccc}
\hline \multicolumn{1}{c}{ Species } & ZMK & $\mathrm{n}$ & $\mathrm{p}$ & $\begin{array}{c}\text { direction } \\
\text { of trend }\end{array}$ \\
\hline $\begin{array}{l}\text { Formica } \\
\text { cunicularia }\end{array}$ & 15.21 & 30 & $<0.0001$ & decrease \\
$\begin{array}{l}\text { Lasius } \\
\text { psammophilus } \\
\begin{array}{l}\text { Plagiolepis } \\
\text { taurica }\end{array}\end{array}$ & 2.9 & 30 & $<0.0001$ & $\begin{array}{c}\text { slight } \\
\text { decrease }\end{array}$ \\
$\begin{array}{l}\text { Tetramorium cf. } \\
\text { caespitum }\end{array}$ & 0.38 & 30 & 6.621 & no trend \\
$\begin{array}{l}\text { Tapinoma } \\
\text { subboreale }\end{array}$ & 0.72 & 30 & 0.553 & no trend \\
\begin{tabular}{l} 
Lasius niger \\
\hline
\end{tabular} & 24.89 & 30 & $<0.0001$ & decrease \\
\hline
\end{tabular}

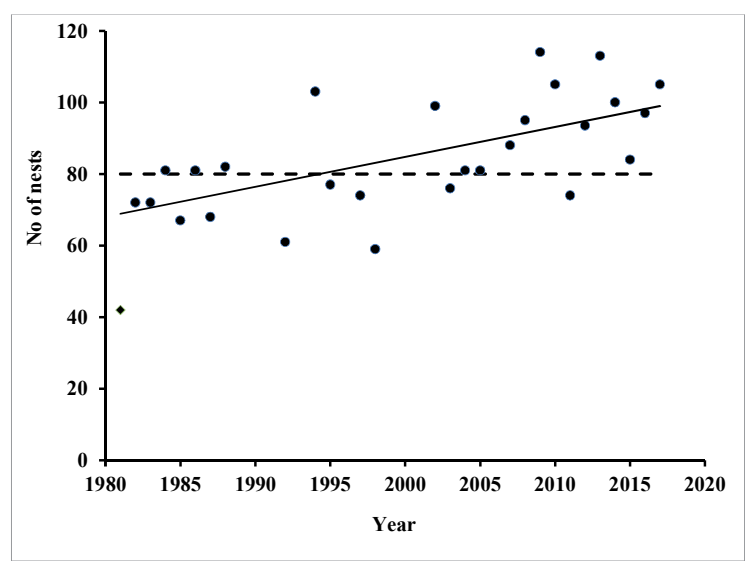

Figure 2. Total number of ant nests under slates in function of time. Dashed line shows the number of slates.

Population trend analyses at the species level (Table 1) have shown that the increase of dune top species group is due to the dynamics of Plagiolepis taurica (slope of change: 1.45), while the population of the other predominant species of the same group, Lasius psammophilus performed a moderate decreasing trend (slope: -0.20). P. taurica was absent from the dune slack at the beginning, but later on its nest density gradually increased there, too $(\mathrm{ZMK}=5.65, \mathrm{p}<0.0001$, Fig. 4), whereas the density of L. psammophilus nests did not tend either to increase or to decrease significantly (ZMK = $0.86, \mathrm{~ns})$ in the slack.

Thus, the original spatial structure of the ant community changed in the studied plots. The populations of the original species group of the slack (Lasius niger, Formica sanguinea, Myrmica schencki, Formica rufibarbis) completely disappeared. Plagiolepis taurica colonized the dune slack, too, and associated there with the transitional species (Tetramorium cf. caespitum and Tapinoma subboreale) and so did Formica cunicularia. Only L. psammophilus and P. taurica remained as predominant populations on the dune tops by the end of the study period.

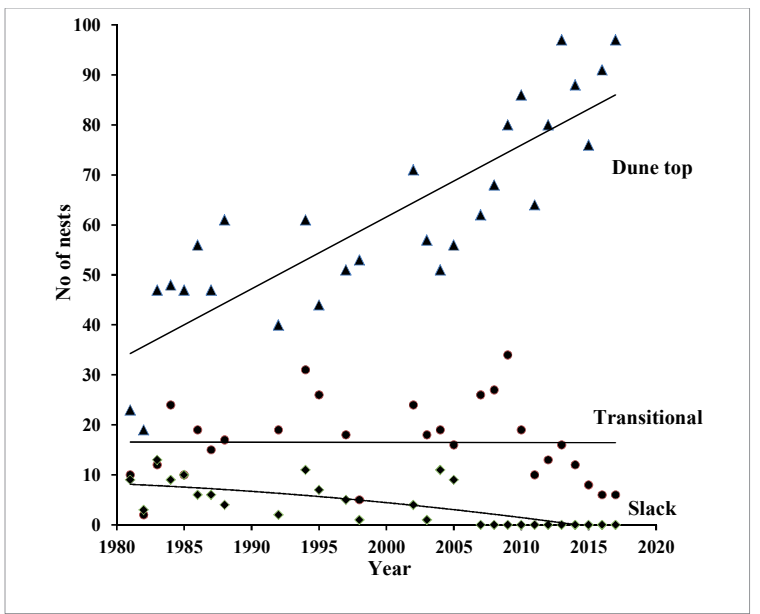

Figure 3. Temporal dynamics of species groups characteristic to different habitat patches

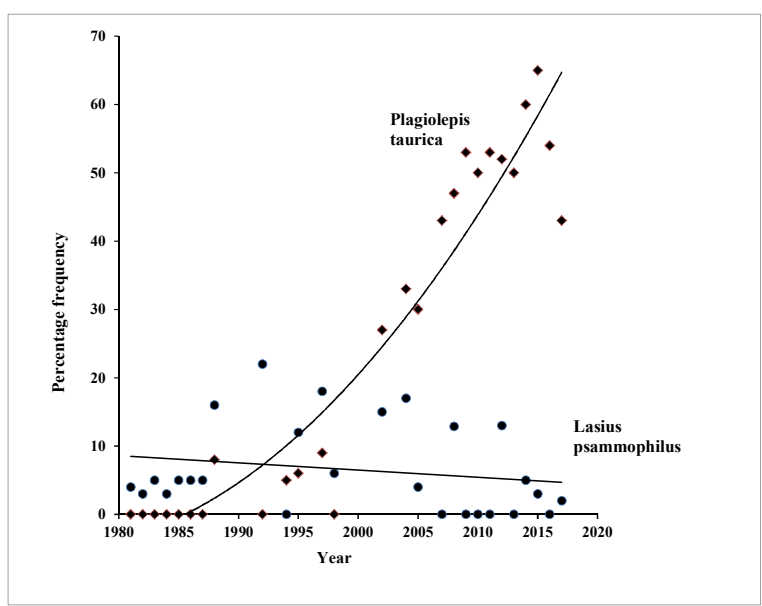

Figure 4. Changes of percentage ratio of dune slack density/ whole density in P. taurica and L. psammophilus

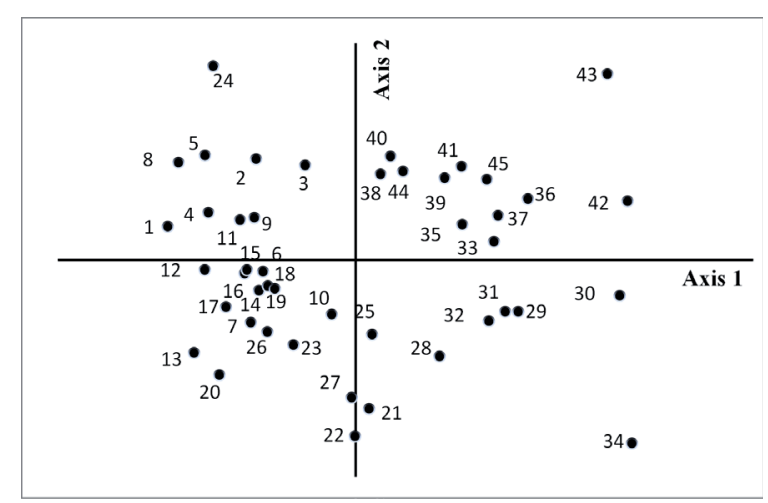

Figure 5. NMDS ordination of sampled ant assemblages during the project period. Numbering indicates consecutive observations.

The NMDS ordination of whole assemblage in the consecutive study periods with the Renkonen similarity function (Fig. 5) shows that community-level change was a more or less continuous process without intensive reversion, as the 


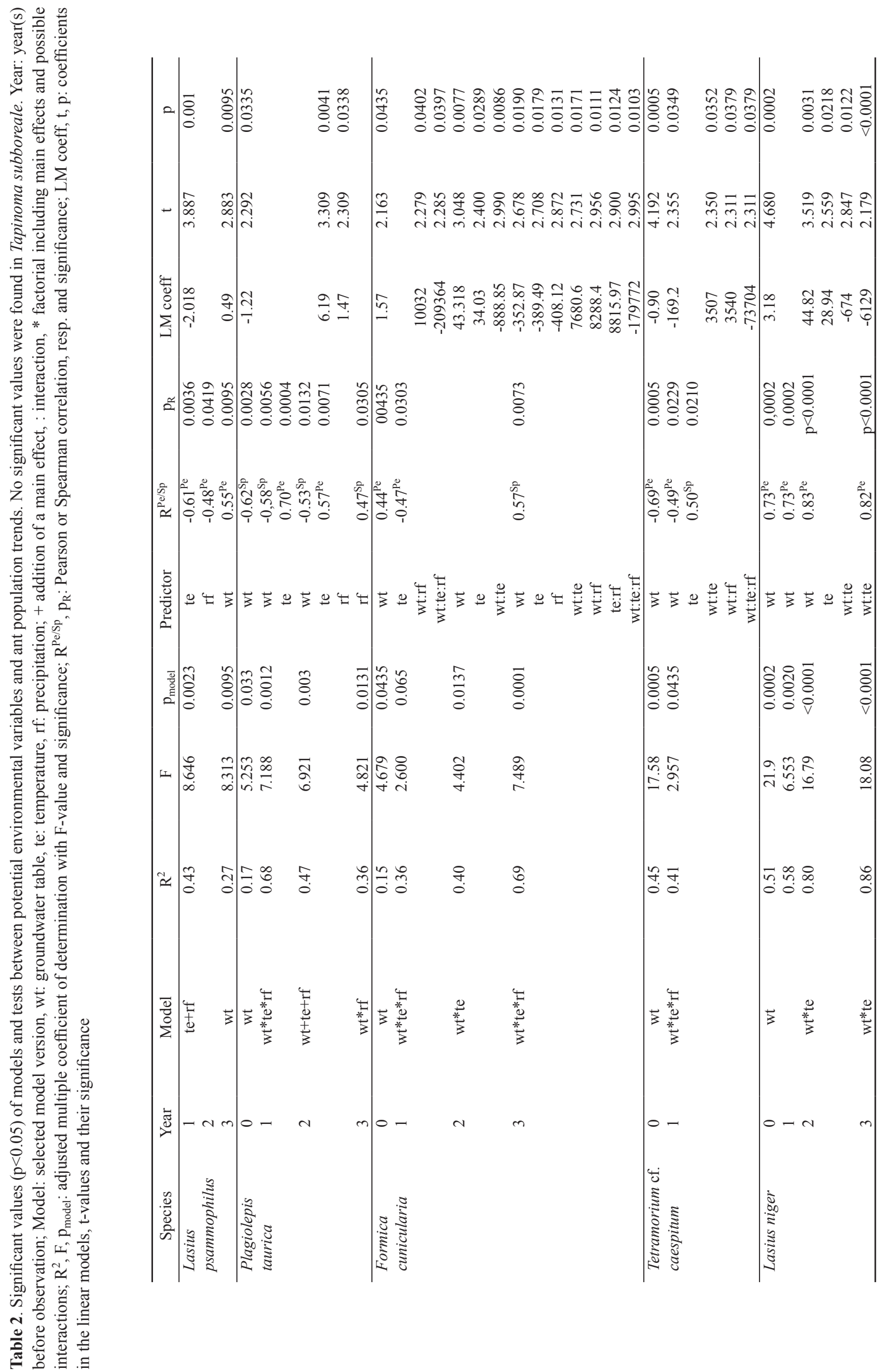


first axis of the ordination plot is correlated with the sequence of observations $(r=0.80 ; p<0.0001)$.

\section{Effects of environmental variables}

Out of the three studied environmental variables, the level of ground water table seems to be the most important predictor affecting ant population dynamics (Table 2). The population trends of Plagiolepis taurica were in negative relationship with the height of ground water table and it was the case with Tetramorium cf. caespitum, too. All other significant relations with ground water table height were positive, even in the case of Lasius psammophilus, which is a typical dune-top ant. No significant relationship was observed in Tapinoma subboreale.

\section{Discussion}

As it was stated in the Introduction, ants are regarded as suitable objects for ecological monitoring (Agosti et al. 2000, New 2000, Andersen et al. 2004, Underwood and Fisher 2006) because of their easy sampling and sensitive indicator character (Andersen 1997, Andersen and Majer 2004, Hoffmann and Andersen 2004, Hodkinson and Jackson 2005, Hoffmann 2010). Monitoring handbooks and manuals (e.g., Elzinga et al. 2001, Hill et al. 2005), however, frequently disregard ants as an invertebrate reference group. It could partly be due to the only difficulty of ant sampling, that their populations are built up of two units, i.e., individuals and colonies. The majority of the above cited works on ant monitoring and even the methodological ones (e.g., Alder and Silverman 2004, King and Porter 2005, de Souza et al. 2012) are restricted to sampling individuals staying outside the nests. A review by Underwood and Fisher (2006) shows that only 9 out of 58 studies of conservation monitoring dealt with "general sampling", which could involve nest sampling, although papers emphasized its significance already from the 1970s (Baroni-Urbani et al. 1978, Gallé 1972, 1986). A combination of the two sampling techniques is also possible (Vepsäläinen et al. 2000). The main drawback of nest sampling could be that the excavation of the soil surface is necessary to reveal all nests in the majority of habitats types, especially in grasslands. However, it is an intensive disturbance threatening the survival of colonies, therefore it makes repeated sampling for continuous monitoring impossible.

We employed slates as artificial shelters to perform nest sampling. The procedure of checking for the presence of ant nests by lifting the slates, is a slight disturbance, that does not damage ant colonies, therefore viable for longer term monitoring. Although ant colonies disappeared from under the slates after the observations, they returned within hours or at most within 3-5 days, performing faster colony movements than published from different sites and situations (Smallwood 1982, Smallwood and Culver 1979, Briano et al. 1995). The sampling technique described in the present paper is not at all new. M. V. Brian first used slates as artificial nesting sites for ants already in 1952 (Brian 1952). Later, M. G. Nielsen applied concrete bricks for the same purpose, similarly in a sand-dune site (Nielsen, personal communication). Other types of artificial nest sites were used by Young (1986) and Herbers and Banschbach (1995).

Regarding the pros and cons, I recommend applying artificial nesting shelters for the long-term monitoring of ant colonies, especially in open habitats. Slate plates of similar size used in this study are especially suitable for this purpose because they are light enough to handle and sufficiently large to provide nesting shelters. Gallé et al (2014) found lower occupation frequency using $10 \mathrm{~cm} \times 10 \mathrm{~cm}$ slates. Calibration of temperature range for highest occupation helps to select the optimal period for observation even on the basis of macrosynoptic whether forecast by meteorological agencies.

From the viewpoint of this study, it is an important question whether slates were really attractive for the ants or the nests occurred under them only by chance, with the same probability as in any other part of an identical area of the same habitat (see also Gallé et al. 2014). I did not estimate the density of nests among the slates during the study period to avoid heavy disturbance by soil excavation. Former nest density estimations via excavation showed that the mean density of ant nests was 1.45 nests $/ \mathrm{m}^{2}$ in the neighbouring parts of the same habitat (Gallé 1980). This is comparable to the figure assessed from the average occupation of slates by the present study $\left(1.56\right.$ nests $\left./ \mathrm{m}^{2}\right)$, indicating that during the spring observation periods nearly all of the nests were under slates.

Another problem is whether large nests occupy more than one slate. This problem was discussed by Gallé et al. (2014) for the quasi polydomous L. psammophilus, which establishes large colonies, the stations of which could occupy several nesting sites (Nielsen 1972, Gallé 1980). However, on the basis of results obtained in earlier density estimations by nest excavation (Gallé 1978, 1980, 1991), it is unlikely that L. psammophilus established brood chambers in more than one shelter. Therefore, the number of slates with the presence of brood or exuvia of pupae could well correspond to the number of nests of L. psammophilus. Single colonies of $T$. cf. caespitum and Formica species could occupy two, three or even more neighbouring slates in the dune slack. That could lead to a slight overestimation of density $(1.56>1.45$, see above), but as it was possible to correct this source of error in most cases already during the field observations, I assess that it did not mean more than one or two nests plus in one year. Data from years when the number of nests exceeded the number of slates indicate plesiobiosis (see Gallé et al. 2014).

Ranges of population fluctuations reported in other longterm and monitoring studies (see Agosti et al. 2000), focused on the dynamics of individuals (i.e., ant workers), exceeded the range of fluctuations presented here. In a 8-yr long continuous period of worker based ant monitoring in the same habitat, we collected a total of 454248 ant workers with 70 pitfall traps between 1981 and 1988 (Gallé et al. unpublished) and the all-population between-year $\mathrm{CV}$ was 0.54 , much greater than in the present study, based on ant nests (0.18). Papers based on colony counting (Chew 1995, Chew and De Vita 1980, Keeler 1993, Brown et al. 1997, Klimetzek 1981, 
Klimetzek et al. 2013), however, described fluctuations of similar or even smaller magnitude in different habitats.

The majority of publications on the effect of climate change on ants, either in geographical or in local ecological scales, deal with the distribution and spread of invasive ant species (Chen 2008, Espadaler and Gómez 2003, RouraPascual et al. 2004, Hartley et al. 2006, 2010, Sutherst and Maywald 2005, Ward 2007, Bertelsmeier et al. 2016). As no occurrence of invasive ant species has been documented from the studied habitat in question, I am not discussing the results of the present paper in the light of those studies, although local density increase of Plagiolepis taurica, which is a thermophilous and drought tolerant species, is similar to the expansion of invasive ant species on larger scales.

In studies of different species and communities, several results demonstrated the effects of temperature on species diversity and other ant community characteristics. In a series of different habitats, Jenkins et al. (2011) found that temperature was the most important single predictor of global ant species density. Likewise, Botes et al. (2006) showed that temperature explained significant proportions of the variation in species density and abundance in the Northern Cape Floristic Region, South Africa. Moreover, results of the study by Machac et al. (2011) highlighted the potential role of environmental temperature, together with niche constraints and competition in shaping broad-scale ant diversity gradients. Sanders et al. (2003), however, suggested that in arid ecosystems, besides lower temperatures, higher precipitation also supports species richness for some taxa. In the present study, the temperature proved to be the second most effective environmental variable (Table 2). Segev (2010) emphasized the significance of precipitation in sandy dune habitats of Israel, where no correlation was found between temperature and ant species richness, whereas annual precipitation and species richness showed a significant unimodal pattern. In North-American dry habitats, long-term census data from populations of different species showed that precipitation influences the survivorship of ant colonies with one-year time lag (Sanders and Gordon 2004). I found few cases when the effect of precipitation was significant with two- or three-year time lags (Table 2).

Table 2 shows that the level of the groundwater table influenced the population trends in most cases. If significant relationships were observed between population trends and environmental variables, the level of groundwater table was always at least one of the significant variables. Therefore, it can be regarded as the most important environmental condition for the long-term dynamics of ant colonies. The effect of groundwater table on ants is assumed by several authors, both in sand dune complexes (Boomsma et al. 1982 and Bonte et al. 2003) and in other habitats (Mabelis and Chardon 2006, Cardoso et al. 2010 and Budianta et al. 2015). Tschinkel et al. (2012) gave the most accurate and detailed analysis of the effect of the groundwater table together with other factors on the distribution of ant species in north Florida pine flatwoods.

The region of the studied site (Kiskunság) is especially exposed to climate change; it is gradually transforming into a semi-desert. World-wide desertification has usually been attributed primarily to human activity, especially to livestock grazing, and secondarily to changes in climate, especially to prolonged and recurrent drought (Brow et al. 1997 and citations therein). The process of desertification is associated with the homogenization of habitats and the decline of habitat complexity, which has a significant negative effect on ant diversity both in successional sand-dune complexes (Gallé 1994) and in other habitats (Lassau and Hochuli 2004). The gradual disappearance of "dune slack" species from study plots of the present study during the observation period well indicates a serious homogenization process. The slack species group is still surviving in decreasing frequency in other, deeper, a bit moister slacks of the same grassland (Gallé 1994, Kanizsai et al. 2009).

The increased frequency of the dune-top species group is due to local habitat expansion by Plagiolepis taurica, which is known from harder soil habitats as well (Gallé et al. 2005 as $P$. vindobonensis), therefore it is able to colonize dune slacks. The other predominant member of the same group, Lasius psammophilus, however, is a typical ant of soft sand habitats with open vegetation (see Gallé 1991, Gallé et al. 1998, Járdán et al. 1993 under the name L. alienus), hardly tolerating the harder soil and other concomitant conditions of the dune slack, therefore its density did not increase there. Another change of species composition is forecasted, as in other dry parts of the same grassland with scarce vegetation, Cataglyphis aenescens has appeared and joined the dune top species group, replacing Formica cunicularia.

The original spatial structure of ant communities outlined in this paper has been a general pattern in sand dune areas of the Pannon Ecoregion especially in Kiskunság (see Járdán et al. 1993, Gallé 1980, 1986, 1994). Community level transformations induced by climate change and especially ground water depletion are leading to gradual rearrangement of communities, homogenization of species composition across habitat types and a considerable decline of diversity, threatening the fauna of the whole region.

Acknowledgements. This study was supported by the Directorate of Kiskunság National Park, the Hungarian Academy of Sciences and the Hungarian National Research Fund. I thank Dr. F. Samu, Dr. R. Gallé and Prof. Dr. D. Klimetzek and three anonymous referees for their helpful and valuable advice and $\mathrm{C}$. Németh for his manifold technical help.

\section{References}

Agosti, D., J.D. Majer, L.E. Alonso and T.R. Schultz (eds) 2000. Ants, Standard Methods for Measuring and Monitoring Biodiversity. Smithsonian Inst. Press, Washington.

Alder, P. and J. Silverman 2004. A comparison of monitoring methods used to detect changes in Argentine ant (Hymenoptera: Formicidae) populations. J. Agric. Urban Entomol. 21:142-149.

Andersen, A.N. 1997. Using ants as bioindicators: Multiscale issues in ant community ecology. Conservation Ecology [online] http:// www.consecol.org/vol1/ iss1/art8/ 
Andersen, A.N. 2010. Using ants as indicators of ecosystem change. In: L. Lach, C.L. Parr and K.L. Abbott (eds), Ant Ecology. Oxford Univ. Press, Oxford, pp. 138-139.

Andersen, A.N. and J.D Majer 2004. Ants show the way down under: invertebrates as bioindicators in land management. Front. Ecol. Environ. 2:291-298.

Andersen, A.N., A. Fisher, B.D. Hoffmann, J.L. Read and R. Richards 2004. Use of terrestrial invertebrates for biodiversity monitoring in Australian rangelands, with particular reference to ants. Austral Ecol. 29:87-92.

Baroni-Urbani, C., G. Josens and G.J. Peakin 1978. Empirical data and demography parameters. In: Brian, M.V. (ed.), Production Ecology of Ants and Termites. Cambridge University Press, Cambridge, pp. 5-44.

Bertelsmeier, C., O. Blight and F. Courchamp, 2016. Invasions of ants (Hymenoptera: Formicidae) in light of global climate change. Myrmecol. News 22:25-42.

Bonte, D., W. Dekoninck, S. Provoost, E. Cosijns and M. Hoffmann 2003. Microgeographical distribution of ants (Hymenoptera: Formicidae) in coastal dune grassland and their relation to the soil structure and vegetation. Anim. Biol. 53:367-377.

Boomsma, J.J., G.A. Van der Lee and T.M. Van der Have 1982. On the production ecology of Lasius niger (Hymenoptera: Formicidae) in successive coastal dune valleys. J. Anim. Ecol. 51:975-991.

Botes, A., M.A. McGeoch, H.H. Robertson, A, Van Niekerk, H.P. Davids, and S.L. Chown, 2006. Ants, altitude and change in the Northern Cape Floristic Region. J. Biogeogr. 33:71-90.

Brian, M.V. 1952. Interaction between ant colonies at an artificial nest-site. Entomol. Mon. Mag. 88:84-88.

Briano, J.A., R.S. Patterson and H.A. Cordo 1995. Colony movement of the black important fire ant (Hymenoptera: Formicidae) in Argentina. Environ. Entomol. 24:1131-1134.

Brown, J.H., T. Valone and C. Curtin 1997. Reorganization of an arid ecosystem in response to recent climatic change. Proc. Natl. Acad. Sci. USA 94:9729-9733.

Budianta, D. and M.R. Ridho 2015. Communities of ants (Hymenoptera: Formicidae) in peatland planted with oil palm stands of different age strata. Adv. Environ. Biol. 2015:473-481.

Cardoso, D.C., T.G. Sobrinho and J.H. Schoereder 2010. Ant community composition and its relationship with phytophysiognomies in a Brazilian Restinga. Insectes Soc. 57:293-301.

Chen, Y. 2008. Global potential distribution of an invasive species, the yellow crazy ant (Anoplolepis gracilipes) under climate change. Integrative Zool. 3:166-175.

Chew, R.M. 1995. Aspects of the ecology of three species of ants (Myrmecocystus spp., Aphaenogaster sp.) in desertified grassland in southeastern Arizona, 1958-1993. Am. Midl. Nat. 134:75-83.

Chew, R.M. and J. De Vita 1980. Foraging characteristics of a desert ant assemblage: Functional morphology and species separation in Cochise County, Arizona. J. Arid Environ. 3:75-83.

Csősz, S., B. Markó and L. Gallé, L., 2011. The myrmecofauna (Hymenoptera: Formicidae) of Hungary: an updated checklist. North-West J. Zool. 7:55-62.

de Souza, J.L.P., F.B. Baccaro, V.L. Landeiro, E. Franklin and W.E. Magnusson 2012. Trade-offs between complementarity and redundancy in the use of different sampling techniques for grounddwelling ant assemblages. Appl. Soil Ecol. 56:63-73.

Dunn, R.R., B. Guenard, M.D. Weiser and N.J. Sanders 2009 Geographic gradients. In: L. Lach, C.L. Parr and K.L. Abbott (eds.) Ant Ecology. Oxford Univ. Press, Oxford, pp. 38-58.
Elzinga, C.L., D.W. Salzer, J.W. Willoghby and J.P. Gibbs 2001. Monitoring Plant and Animal Populations. Blackwell Science, Oxford.

Espadaler, X. and C. Gómez 2003. The Argentine ant, Linepithema humile, in the Iberian peninsula. Sociobiology 42:187-192.

Folgarait, P.J. 1998. Ant biodiversity and its relationship to ecosystem functioning: a review. Biodivers. Conserv. 7:1221-1244.

Gallé, L. 1972. Study of ant populations in various grassland ecosystems. Acta Biol. Szeged. 18:159-164.

Gallé, L. 1978. Dispersion of the nests of an ant species (Hymenoptera: Formicidae). Acta Biol. Szeged. 18:105-109.

Gallé, L. 1980. Dispersion of high density ant populations in sandy soil grassland ecosystems. Acta Biol. Szeged 26:129-135.

Gallé, L. 1986. Habitat and niche analysis of grassland ants. Entomol. Gen. 11:197-211.

Gallé, L. 1991. Structure and succession of ant assemblages in a north European sand dune area. Ecography 14:31-37.

Gallé, L. 1994. Formicoidea közösségek szerveződése. (Organization of Formicoidea communities). DSc Thesis, Szeged, 1-125.

Gallé, L. and G. Szőnyi 1988. A check list of ants (Hymenoptera: Formicoidea) of a sandy grassland in Kiskunság National Park (Hungary). Acta Biol. Szeged. 34:167-168.

Gallé, L., L. Körmöczi, E. Hornung and J. Kerekes 1998. Sructure of ant assemblages in a Middle-European successional sand-dune area. Tiscia 31:19-28.

Gallé, L., B. Markó, K. Kiss, É. Kovács, H. Dürgö, K. Kőváry and S. Csősz 2005. Ant fauna of River Tisza basin (Hymenoptera: Formicidae). Tiscia Monogr. Ser. 7:149-197.

Gallé, L., O. Kanizsai, I. Maák, and G. Lőrinczi, 2014. Close nesting association of two ant species in artificial shelters: Results from a long-term experiment. Acta Zool. Hung. 60:359-370.

Gilbert, R.O. 1987. Statistical Methods for Environmental Pollution Monitoring. Van Nostrand Reinhold, New York.

Hartley, S., R. Harris, R.J. Philip 2006. Quantifying uncertainty in the potential distribution of an invasive species: climate and the Argentine ant. Ecol. Lett. 9:1068-1079.

Hartley, S., P.D. Krushelnycky, and P.J. Lester 2010. Integrating physiology, population dynamics and climate to make multi-scale predictions for the spread of an invasive insect: the Argentine ant at Haleakala National Park, Hawaii. Ecography 33:83-94.

Herbers, J.M. and V. Banschbac 1995. Size-dependent nest site choice by cavity-dwelling ants. Psyche 102:13-17.

Hill, D., M. Fasham, G. Tucker, M. Shewry and P. Show 2005 Handbook of Biodiversity: Methods, survey, evaluation and monitoring. Cambridge Univ. Press, Cambridge.

Hodkinson, A.D. and J.K. Jackson 2005. Terrestrial and aquatic invertebrates as bioindicators for environmental monitoring, with particular reference to mountain ecosystems. Environ. Manage. $35: 649-666$.

Hoffmann, B.D. 2010. Using ants for rangeland monitoring: Global patterns in the responses of ant communities to grazing. Ecol. Indic. 10:105-111.

Hoffmann, B.D. and A.N. Andersen 2003. Responses of ants to disturbance in Australia, with particular reference to functional groups. Austral. Ecol. 28: 444-464.

Járdán, Cs., L. Gallé and K. Margóczi 1993. Ant community composition in a Hungarian successional sand dune area. Tiscia 27:9-15.

Jenkins, C.N., N.J. Sanders, A.N. Andersen, X. Arnan, C.A. Brühl, X. Cerda, ... and A.D. Gove 2011. Global diversity in light of climate change: the case of ants. Divers. Distrib. 17:652-662. 
Kanizsai, O., H. Dürgő, G. Szőnyi, L. Gallé 2009. Hangyaközösségek hosszútávú dinamizmusa a bugaci pusztán (Long-term community dynamics of ants at Bugac puszta, in Hungarian). In: L. Gallé (ed.), Entomológia: kutatás, szemléletformálás, ismeretterjesztés. SZTE Ökológiai Tanszék, Szeged, pp. 179-190.

Kanizsai, O., R. Gallé and L. Gallé 2009. Perception of spatial patchiness by ant assemblages. Tiscia 37:3-7.

Keeler, K.H. 1993. Fifteen years of colony dynamics in Pogonomyrmex occidentalis, the western harvester ant, in western Nebraska. Southwest. Nat. 38:1229-1232.

King, J.A. and S.D. Porter 2005. Evaluation of sampling methods and species richness estimators for ants in upland ecosystems in Florida. Environ. Entomol. 34:1566-1578.

Klimetzek, D. 1981. Population studies on hill building wood-ants of the Formica rufa-group. Oecologia 48:418-421.

Klimetzek, D., H.P. Gewiss, and N.Parthey 2013. 44 years of settlement behavior and population dynamics of hill-building wood ants (1966-2010) in Freiburg area (SW-Germany). $5^{\text {th }}$ Centr. Eur. Workshop Myrmecology, Innsbruck, Abstract Book, p. 86.

Ladányi, Z., V. Blanka, B. Meyer, G. Mezősi and J. Rakonczai 2015. Multi-indicator sensitivity analysis of climate change effects on landscapes in the Kiskunság National Park, Hungary. Ecol. Indic. 58:8-20.

Lassau, S.A. and D.F. Hochuli 2004. Effects of habitat complexity on ant assemblages. Ecography 27:157-164.

Levia Jr, D.F. and E.E. Frost 2004. Assessment of climatic suitability for the expansion of Solenopsis invicta Buren in Oklahoma using three general circulation models. Theor. Appl. Climatol. 79:23-30.

Lindenmayer, D.B., P. Gibbons, M. Bourke, et al. 2012. Improving biodiversity monitoring. Austral Ecol. 37:285-294.

Mabelis, A.A. and J.P. Chardon 2006. Survival of the trunk ant (Formica truncorum Fabricius, 1804; Hymenoptera: Formicidae) in a fragmented habitat. Myrmecol. News 9:1-11.

Machac, A., M. Janda, R.R. Dunn and N.J. Sanders 2011. Elevational gradients in phylogenetic structure of ant communities reveal the interplay of biotic and abiotic constraints on diversity. Ecography 34:364-371.

Magurran, A. E., S. R. Baillie, S. T. Buckland, J. M. Dick, D.A. Elston, E.M. Scott, R.I. Smith, P.J. Somerfield and A.D. Watt 2010. Long-term datasets in biodiversity research and monitoring: assessing change in ecological communities through time. Trends Ecol. Evol. 25:574-582.

Morrison, L.W., M.D. Korzukhin and S. D. Porter 2005. Predicted range expansion of the invasive fire ant, Solenopsis invicta, in the eastern United States based on the VEMAP global warming scenario. Divers. Distrib. 11:199-204

New, T.R. 2000. How useful are ant assemblages for monitoring habitat disturbance on grasslands in south eastern Australia? $J$. Insect Conserv. 4:153-159.

Nielsen, M.G. 1972. An attempt to estimate energy flow through a population of workers of Lasius alienus (Först) (Hymenoptera: Formicidae). Natura Jutl. 16:97-107.

R Core Team 2014. R: A language and environment for statistical computing. R Foundation for Statistical Computing, Vienna, Austria. URL http://www.R-project.org/.

Rakonczai J. 2011. Effects and consequences of global climate change in the Carpathian Basin. In: J. Blanco, H. Kheradmand (eds.), Climate Change - Geophysical Foundations and Ecological Effects. InTech, Rijeka. pp. 297-322.
Rakonczai J. and Zs. Ladányi (eds.) 2012. Review of climate change research program at the University of Szeged (2010-2012). Univ, Szeged, Fac. Sci. Inform., Sect. Geogr. Geol., Szeged.

Rakonczai J. and Zs. Fehér 2015. A klímaváltozás szerepe az Alföld talajvízkészleteinek időbeli változásaiban (Role of climate change in temporal trends of groundwater level in the Great Hungarian Plan, in Hungarian). Hidrológiai Közlöny 95:1-15.

Roura-Pascual, N., A.V. Suarez, C. Gómez, P. Pons, Y. Touyama, A.L. Wild and A.T. Peterson 2004. Geographical potential of argentine ants (Linepithema humile Mayr) in the face of global climate change. Proc. Roy. Soc. B. Biol. Sci. 271:2527-2535.

Sanders, N.J. and D.M. Gordon 2004. The interactive effects of climate, life history and interspecific neighbours on mortality in a population of seed harvester ants. Ecol. Entomol. 29:632-637.

Sanders, N.J., J. Moss, and D. Wagner 2003. Patterns of ant species richness along elevational gradients in an arid ecosystem. Global Ecol. Biogeogr. 12:93-102.

Segev, U. 2010. Regional patterns of ant-species richness in an arid region: The importance of climate and biogeography. J. Arid Environ. 74:646-652.

Simon, T. 1992. A magyarországi edényes flóra határozója. Harasztok - virágos növények. Tankönyvkiadó, Budapest.

Smallwood, J. 1982. Nest relocation in ants. Insectes Soc. 29:138-147.

Smallwood, J. and D.C. Culver 1979. Colony movement of some North American ants. J. Anim. Ecol. 48:373-382.

Suarez, A.V., T.P. McGlynn and N.D. Tsutsui 2010. Biogeographic and taxonomic patterns of introduced ants. In: L. Lach, C.L. Parr, K.L. Abbott (eds), Ant Ecology. Oxford University Press, Oxford. pp. 233-244.

Sutherst, R.W. and G. Maywald 2005. A climate model of the red imported fire ant, Solenopsis invicta Buren (Hymenoptera: Formicidae). Implications for invasion of new regions, particularly Oceania. Environ. Entomol. 34:317-335.

Thomsen, P., J.O.S. Kielgast, L.L. Iversen, C. Wiuf, M. Rasmussen, M.T.P. Gilbert et al. 2012. Monitoring endangered freshwater biodiversity using environmental DNA. Mol. Ecol. 21:2565-2573.

Tschinkel, W.R., T. Murdock, J.R. King and C. Kwapich. 2012. Ant distribution in relation to ground water in North Florida pine flatwoods. J. Insect Sci. 12:114.

Underwood, E.C. and B.L. Fisher 2006. The role of ants in conservation monitoring: If, when and how. Biol. Conserv. 132:166-182.

Vepsäläinen, K, R. Savolainen, J. Tiainen and J. Vilen 2000. Successional changes of ant assemblages: from virgin and ditched bogs to forests. Ann. Zool. Fenn. 37:135-149.

Ward, D.F. 2007. Modeling the potential geographic distribution of invasive ant species in New Zealand. Biol. Invasions 9:723-735.

Young, A.M. 1986. Notes on the distribution and abundance of ground- and arboreal-nesting ants (Hymenoptera: Formicidae) in some Costa Rican cacao habitats. P. Entomol. Soc. Wash. $88: 550-571$.

Received January 2, 2017

Revised May 26, June 12, 2017

Accepted July 6, 2017

Open Access. This article is distributed under the terms of the Creative Commons Attribution 4.0 International License (https://creativecommons.org/licenses/by/4.0/), which permits unrestricted use, distribution, and reproduction in any medium, provided the original author and source are credited, you give a link to the Creative Commons License, and indicate if changes were made. 